\title{
Zakat (Alms-Giving) Management In Indonesia: Whose Job Should It Be?
}

\author{
Oleh: Zulkipli Lessy ${ }^{1}$
}

\begin{abstract}
Zakat has been the source of Islamic social welfare for centuries. How zakat is linked with Islamic social welfare will be analyzed both as religious teachings and as actual practices in Indonesia. The problems of zakat in Indonesia which will be highlighted are: a failure to reach the target level; the problem of zakat versus tax; and the problem of Acts No. 38 Year 1999. This paper will discuss the roles of Rumah Zakat Indonesia (RZI) in trying to eradicate poverty. This paper concludes that private zakat institutions have tremendous efforts to improve the welfare of Indonesia. The government, however, wants to enact legislature to ensure that private zakat institutions are under state control. This paper suggests that the government and private zakat institutions should collaborate instead of competing with each other.
\end{abstract}

Keywords: Zakat, infaq, shadaqah, waqf, qurban, BAZ, LAZ, Islamic welfare.

\section{Introduction}

This paper will discuss the development of zakat management to improve Islamic social welfare in Indonesia. Major issues in this paper are the elements of Islamic welfare efforts, the advancement of zakat institutions, and Muslims' misperceptions about zakat fitrah and zakat maal. Additionally, this paper will discuss the role of the Indonesian government in regulating zakat and will highlight problems arising from the regulation. It will also discuss the role of Rumah Zakat Indonesia (RZI), one of the zakat collecting institutions founded to improve Islamic social welfare through its philanthropic activities.

Because zakat is an institution related to public welfare, government and private zakat institutions should collaborate to eliminate poverty instead of competing for zakat funds. In order to receive the public trust, they should involve external auditors in assessing their funds, and should report the results of audits to the public to educate society and also to encourage people toward giving zakat. Lagging behind the private zakat institutions in collecting and distributing zakat, the government zakat institution should learn from the private zakat institutions which have sustainable programs to empower the poor.

The organization of this paper will be as follows: (1) introduction; (2) literature review which consists of discussions about the basic concept of zakat in the Qur'an, the elements of Islamic welfare efforts and mechanisms of zakat; (3) zakat institutions in Indonesia; (4) problems with government regulation of zakat; (5) the programs of the Rumah Zakat Indonesia; and (6) conclusions.

${ }^{1}$ Lecturer at the Faculty of Tarbiyah UIN Sunan Kalijaga Yogyakarta, Indonesia. Email: zulkifid@yahoo.com. 
Zulkipli Lessy: Zakat (Alms-Giving) Management...

\section{Literature Review}

Muslim countries, such as Indonesia, Malaysia, Pakistan, Bangladesh, Saudi Arabia, and Turkey, have developed zakat institutions to improve Islamic social welfare. They also have managed zakat for public welfare. Indonesia is the country which has the largest Muslim population in the world, so Islamic social welfare of zakat is an idealized source. Of 220 million people in Indonesia, 87\% are Muslims (191 million), of which 40\% (76.5 million) are capable Muslims who are obligated to pay zakat. This should mean that zakat potential to alleviate poverty and promote social well-being is vast if it can be organized effectively (Doa, 2005).

\section{A. Basic Concept of Zakat in the Qur'an}

Zakat is identified as an Islamic social welfare practice because it is an obligation for every capable Muslim to give his or her possessions to specified groups that have the right to them. Eight groups of people are entitled to receive zakat according to the Qur'an.

The shadaqah (zakat) are for: the poor; the destitute; the agents employed therein; those whose hearts are to be won over; the freedom of slaves; the (relief of) debtors; expenditure in the way of Allah; the follower of the way---an ordinance from Allah. (Khalidi, 2008, p. 181)

The Qur'an stresses the importance of zakat, which it considers as obligatory as prayer. Frequently, the word "prayer" in the Qur'an is followed by that of "zakat."

...Those who have [Sic] have believed in Allah and the Last Day and the angels and the Book and the prophets, and who, though they love their wealth, bestow it upon relatives, and orphans and the poor, upon the followers of the way, and the beggars, and for (the ransoming) of captives; who observe the Prayer and pay the Zakat...(Khalidi, 2008, p. 24)

Noval (1982) noted that the Qur'an contains 32 verses referencing zakat. In most of the verses, zakat is coupled with prayers. This emphasizes the importance which the Qur'an places upon zakat. In the the Qur'an, God has promised great reward to all who fulfill zakat.

And establish regular prayers and pay the zakat and loan to God a goodly loan. Whatever good you send forth before you for your souls, you shall find it in God's presence, better and greater in reward... (Noval, 1982, p. 7)

Furthermore, Noval (1982) emphasized that Muhammad mentions zakat as being one of the five pillars of Islam.

Islam is built upon five pillars---testimony of belief in one God and Muhammad as His prophet, prayers, zakat, fasting in the month of Ramadan and the pilgrimage to Mecca. (Noval, 1982, p. 9) 
Zulkipli Lessy: Zakat (Alms-Giving) Management...

\section{B. Elements of Islamic Welfare Institutions}

Muslims have six potential resources for their social security. The elements are zakat (alms-giving and religiously obligatory tax), infaq, hibah, shadaqah (voluntary giving, charity), waqf (philanthropic endowment), and qurban (slaughtering). The next paragraphs will explain these elements.

\section{Zakat}

Zakat upholds the pre-Islamic traditions of tithing and alms-giving of the pagan, Jewish and Christian traditions; in fact, similar terms with similar meanings can be found in several ancient languages, such as the Aramaic's 'rakutha,' which means 'purity.' Zakat contains a moral imperative and is therefore obligatory because God in the Qur'an orders Muslims to contribute (Kozlowski, 1998). Besides "purity," zakat also means "development" because it grants a fundamental right to the destitute and the needy (Khalidi, 2008). Because zakat provides money to the poor, money will circulate more freely within the Muslim community, and will stimulate the economy in Muslim society (Qardhawi, 2007). Zakat also contains the principle of social justice and wealth redistribution for the eight groups of righteous recipients.

Hassan (2006) mentioned that zakat has two categories, namely zakat fitrah (individuals) and zakat maal (wealth). Capable Muslims have to pay zakat fitrah once a year during Ramadan (fasting month). Traditionally, Indonesian Muslims pay zakat fitrah to the poor in the form of food or its monetary equivalent (not money itself).

Noval (1982) reported that the Hanafi sect allows Muslims to pay zakat fitrah in cash. Indeed, the sect considers this to be preferable because it is more useful to the poor, who know individually what they need most - it might be food or it might be medicine. Zakat fitrah has many uses for those who receive it and for society as a whole.

While zakat maal is also paid once a year, the date is not fixed. Djuanda, et al. (2006) stressed that zakat maal is paid based on the Qur'an and earlier Muslim traditions, when Muslims' wealth has reached the minimum exemption rate. The provision of zakat is a flat $2.5 \%$ on economic returns in general, except for the rate of farm output. Kahf (2004) noted that the flat amount includes farm animals, farm outputs, land, money, jewelry and industrial productions. For example, if a Muslim's annual income is 10 million rupiah, he or she would be expected to give 250,000 rupiah as zakat.

\section{Infaq}

Infaq is a direct voluntary giving (usually in the form of financial giving) to poor individuals, orphans, and people who are in difficult situations due to disasters or to institutions with the primary intent of promoting family and public well-being. The disbursement of infaq is encouraged whenever Muslims receive any kind of income, either regular income or non-regular income such as bonuses or gifts (Ali, 1998). Senturk (2007) reported that infaq derives from the word 'anfaqa' which means giving wealth for particular needs. Infaq is 
Zulkipli Lessy: Zakat (Alms-Giving) Management...

different from zakat in that there is no law regulating the exemption rate. Infaq recipients are not delineated in the manner of zakat with its eight groups.

\section{Hibah}

Hibah is the act of giving something to someone freely and any time without the receiver doing anything in return. Hibah can also be called a gift (Suyitno, et al., 2005). Furthermore, Sabiq (1992) defined the word 'bibab' as 'to pass' or 'to deliver.' This definition signifies something to be passed from the giver's hand to the receiver's. This refers to an act of giving properties to someone without an expected reward. The giving occurs when the giver is alive.

\section{Shadaqah}

Shaik (1980) defined shadaqah as voluntary giving which is done by a Muslim to other Muslims or to non-Muslims, especially poor people. There is no regulated time for people to give shadaqah. There is also no regulation regarding the amount of money which will be donated, so long as it will not make the giver become poor. Shadaqah includes both material things and services that are meaningful for the recipients. For example, someone who teaches children without seeking to be paid is providing a form of shadaqah. Shadaqah has a broad meaning, and the Qur'an uses the word 'shadaqah' for any kind of voluntary contribution.

\section{Waqf}

Waqf literally means holding a certain amount of money, land, or means of production as an endowment to be used for charitable and religious purposes. Since waqf is a form of individual or family contribution for the promotion of social welfare, it can be given only to communities and public institutions, but not to individuals. According to Arjomand (1998), this tradition is not rooted in the Qur'an, but was invented by Islamic juries in the 8th century. According to McChesney (1991), in the 15th century in Central Asia, the mosques and madrasabs (schools) were maintained by waqf income. The staff and users of these institutions received salaries and stipends from waqf revenue to perpetuate a cultural tradition. In Indonesia, Muslims typically give waqf in the form of land on which to build mosques and schools.

\section{Qurban}

Ali (1998) reported that qurban is a specific form of shadaqah in which meat is given primarily to the poor after slaughtering. Qurban is given yearly in the month of haij (pilgrimage). The meats of qurban are usually goat and cow. Qurban originally symbolized the sacrifice of a Muslim through his or her donation of some portion of his or her wealth for the social welfare of the poor. The term 'qurban' is rooted in the experience of Abraham, who was ordered by God to sacrifice his son Ishmael as proof of his love for God. Muslims are encouraged to slaughter lawfully edible animals at least once in their lives.

Volume III, No. 1, Juli 2009 
Zulkipli Lessy: Zakat (Alms-Giving) Management...

\section{Mechanisms of Zakat}

Zakat was instituted in the 7th century. At that time, the characteristics of the obligation were general and did not include details of donations and amount be paid. Practically, the amount of zakat varied according to each Muslim's impulses to philanthropy and their altruism. In the 8th century, Muslim scholars interpreted zakat as obliged in greater specificity in the Qur'an (Qardhawi, 2005). The details of this responsibility are explained in at-Taubah: 60 , which specifies the eight groups entitled to zakat. Many Indonesian Muslims think that zakat recipients are only Muslims as specified in the Qur'an. However, a Jordanian Muslim scholar, alKhayyat suggested that zakat can be given to non-Muslims. He interpreted word 'al-fuqara' (the poor) in at-Taubah: 60 must mean in Arabic 'all the [categories of the] poor', and therefore it must include non-Muslims (Benthall, 1999).

Benthall (1999) suggested that such interpretation is possible because the Qur'an only gives broad lines about zakat recipients but does not specify that Muslims are the only recipients. However, Muslim scholars such as Qardhawi and al-Zuhaili believe that zakat should not be given to non-Muslims. Besides barring non-Muslims as recipients, these scholars also said that zakat cannot be distributed in any of the following ways: (1) to build or finance public facilities such as bridges and mosques (unless the mosques are for 'muallaf' (the faithful)who live in nonMuslim countries); (2) for rich Muslims; (3) for Muslims who are able to work and fulfill their own basic needs; (4) for non-Muslims; (5) for the child or parent or wife of zakat giver; and (6) for members of the Prophet Muhammad's tribes.

This writer does not agree with the first category because public facilities are important. Even public facilities are under the government's responsibility; when the government is unable to build these facilities, then society has the responsibility to build them using zakat funds. This writer also does not agree with the fourth category because Muslims and other faith adherents live in one community. Therefore, it is not wise to exclude those who have not converted to Islam to receive zakat.

Al-Khayyat's perception is that zakat can be given to poor non-Muslims because the Qur'an does not explain whether the word fuqara (the poor) refers to Muslims or non-Muslims. This unclear word can be interpreted as non-Muslim poor who can receive zakat because the Prophet Muhammad said: "I swear by whom my soul is in His hand, you will not enter paradise until you believe, and you will not believe until you love each other" (Sabiq, 1992, p. 3). Loving each other means also loving non-Muslims. So when there are non-Muslim poor, Muslims should help them with zakat funds. Islamic teachings place stress on the public good rather than on a particular entity's interests.

According to Mas'udi (1995), zakat is the only deed in Islam that is concerned with equal access to material resources. The basic concept of zakat as a redistribution mechanism of wealth is that it shall distribute $2.5 \%$ of possessions from the haves - those who have more than they need in their daily lives - to the bave-nots. Islam maintains that the haves should contribute zakat voluntarily. But, because humans suffer from the passion of love of possessions, the presence of zakat institutions is considered necessary. 
Zulkipli Lessy: Zakat (Alms-Giving) Management...

\section{Zakat Institutions in Indonesia}

The bayt al-maal (house of treasure) was established to collect zakat during the era of Caliph Omar, the second successor of the Prophet Muhammad in the 8th century. Because Indonesia has a political system, not an Islamic system, the appointment of collectors and distributors, as well as the establishment of the bayt al-maal, does not depend upon governmental approval. Trusted leaders of the community have the potential to become the collectors and distributors of zakat. They also manage infaq, hibah, shadaqah, qurban and waqf (Qardhawi, 2005).

In relation to the urgency of establishing zakat institutions, Ali (1998) suggested that zakat is not merely a payment like a tax, but zakat should be a state institution, or if there is no Muslim state, it should be a national institution to be run by the people. The practice of zakat should follow shari'a, which orders the calculation and payment of zakat. The government and community institutions established by the people should collect and distribute zakat. The Qur'an determines that one of the entitlement groups is listed as the collectors and distributors of zakat. This indicates that the zakat institutions may become part of the government.

Djatnika (1982) said that in early Indonesian history, mosques and madrasabs were institutions managing zakat when Muslim Javanese began to build the mosques and the madrasabs as their religious educational institutions. Salim (2008) maintained that during the Dutch era in Indonesia, religious leaders took part in collecting and distributing zakat. The Muslim religious leaders used zakat funds for education and welfare of the people and for fighting against the Dutch colonization. The practice did not last long because the Dutch administration created effective control of zakat institutions. The political aim of the Dutch control over zakat was to take a financial source away from Indonesian Muslims and weaken the struggle against the colonization.

Traditionally, Muslims give zakat, infaq and shadaqah (ZIS) directly to the needy, but agents were employed to collect and distribute ZIS in the mosques and the madrasabs. The traditional type of direct giving to individuals is still followed by some Muslims but some now apply the institutional type. A study said that $15 \%$ of Muslims give directly to individuals in Indonesia, while $85 \%$ pay zakat through institutions (PIRAC, 2005). Many of the smaller groups of Muslims who continue to give their alms-giving traditionally have doubts about the accountability and methods of zakat institutions.

Societal doubt about zakat institutions is understandable because many politicians and bureaucrats have been arrested for corruption. Givers are afraid to pay zakat to the institutions because they think that it will be stolen.Corruption in philantropic sectors occurs not only in Indonesia but also in Iran. Benthall (1999) said there is massive corruption in Iran in the philanthropic institutions due to lack of financial accountability. Again, there may be no transparency in service delivery and institutional management. Additionally, the philanthropic sectors may lack public control over charity they give. Donors may assume that those who work in the philanthropic sector are always trustworthy and never abuse charity, or donors may think that because charity abuse is taboo, no one will commit such deeds.

Volume III, No. 1, Juli 2009 
Zulkipli Lessy: Zakat (Alms-Giving) Management...

In the era of President Soeharto (1966-1998), zakat institutions were not transparent to the public about how much money the institutions collected and distributed. Society as a whole was justifiably worried about accountability. The public largely felt that by means of direct giving, they could be certain about who received their donations, but that if they gave zakat through institutions, they might not know who would receive the zakat. Accordingly, there are three sources of doubt: (1) Distribution--some Indonesian Muslims doubt whether their zakat was received by the needy; (2) location--issues relate to access to pay; they may think that it is difficult to go to zakat institutions instead of going to mosques; (3) timing-therZe is misunderstanding about whether they can pay zakat property any time. They may not realize it is not necessary to pay zakat at the same time as paying zakat fitrah ("Profil," 2007).

In Indonesia, an urban neighborhood generally has a mosque, and each mosque enables nearby community members to give their zakat to the collectors in the mosque. Government and community zakat institutions are most often located in urban areas, but this situation may not inspire more distant villagers to pay their zakat to centralized institutions ("Pengelolaan," 2008).

Modern zakat management in Indonesia began in the early 20th century. Muhammadiyah, which is the second largest socio-religious organization, created a national zakat institution. The function of this institution was to be an intermediary institution that collected zakat from payers to the eight entitlement groups specified in the Qur'an. After Indonesia received its independence in 1945, the Aceh Provincial government officially opened a zakat institution, but zakat management continued on a local community basis. There were no mutual programs established to link one province to another for zakat collection and distribution (Ali, 1998).

Today, there are two zakat institutions: the state-supported Zakat Collecting Board (BAZ) and the privately run institution of National Zakat Collectors (LAZ). LAZ has over 20 regional offices and only 18 major national-category offices. Of these $18 \mathrm{LAZ}$ offices, five are considered to have the largest overall roles in society, along with BAZ as the sixth largest agency. In 2008, LAZ collected 236 billion rupiah through its five biggest offices, while BAZ collected only 16 billion rupiah, as shown in Table 1.

Table 1. The Six Largest Zakat Institutions in Indonesia in 2008

\begin{tabular}{|l|l|l|l|}
\hline \multicolumn{1}{|c|}{ Name of Institution } & $\begin{array}{c}\text { Rupiah } \\
\text { (in } \\
\text { billions) }\end{array}$ & $\begin{array}{c}\text { Zakat } \\
\mathbf{( \% )}\end{array}$ & $\begin{array}{l}\text { Infaq, Shadaqah \& } \\
\text { Waqf (\%) }\end{array}$ \\
\hline Dompet Dhuafa (private) & 75 & 70 & 30 \\
\hline Rumah Zakat (private) & 71 & 50 & 50 \\
\hline Pos Keadilan Peduli Umat (private) & 35 & 70 & 30 \\
\hline Yayasan Dana Sosial (private) & 35 & 30 & 70 \\
\hline Dompet Peduli Ummat (private) & 20 & - & - \\
\hline BAZ (state) & 16 & - & - \\
\hline
\end{tabular}


Zulkipli Lessy: Zakat (Alms-Giving) Management...

Note. Adapted from Forum Zakat for the Corporation Seminar held on July 7th, 1997. Forum Zakat was declared, which at the beginning was a consortium of 11 institutions, such as Dompet Dhuafa Republika, Bank Bumi Daya, Pertamina, Telkom Jakarta, Bayt al-Maal Pupuk Kujang, Bazis DKI, Hotel Indonesia and College of Economics Indonesia (STEI). "Zakat management in Indonesia and zakat global synergy" by A. Juwaini (2009). Retrieved from http://amilzakat.blogspot.com.

\section{Problems with Government Regulation of Zakat}

In 1999, Indonesia for the first time passed legislation about zakat management, namely Acts No. 38 Year 1999, to monitor the activities of state-run BAZ and the privately run LAZ. Now there is a push to amend Acts No. 38 Year 1999 so that the government can monopolize and completely nationalize zakat institutions. However, Zakat Forum and zakat collector organizations oppose this amendment because they are worried that the government is not able solely on its own to improve zakat management (Bamualim \& Abubakar, 2005).

Former Minister of Religious Affairs Maftuh Basyuni pointed out three proposed changes. (1) The Acts No. 38 Year 1999 about zakat management should be revised; (2) there should be sanctions for zakat payers who disobey their obligations; (3) BAZ should become the only zakat institution in terms of collection and distribution of zakat from the central to the small unit structures of the government (lurah). However, this last point has triggered a controversy spurred by LAZ, which claims their accomplishment has been to serve the public better than BAZ. LAZ also stated that unrealized zakat payer potential is so significant that the number of zakat institutions working with society now are too few to meet the needs of both the payers and the entitled.

The Acts No. 38 Year 1999 was issued to fulfill the interest of the government to take over public assets. Chapter 6 of these acts gave authority to the government to establish BAZ offices in every region across the country. According to Chapter 7, the community has the authority to establish LAZ offices. Institution building for zakat management is offered by both BAZ and LAZ. Both entities are concerned with developing the social economy. Both institutions not only compete with one another, but also help each other. Moreover, they have limitations and advantages in the optimization of zakat. The private organizations have no bureaucratic matrices, while the government has lost its accountability due to corruption caused by elites in the bureaucracy ("Komisi," 2009).

The competition between BAZ and LAZ is often framed with a motto: "fair competition in doing good" ("Dompet," 2009). This competition reflects the unity orientation in zakat management. Politically, the basis for community cooperation focuses on horizontal interactions. On the other side, the consolidation focuses on a vertical line in the bureaucracy which creates regulations, possibly to the advantage of zakat management by the government (Doa, 2005).

Saepullah (2001) believed that the idea of unification of BAZ and LAZ as issued in Chapters 21-24, Ministry of Religious Affairs No. 581 Year 1999 seemed to restrict LAZ. He maintained that zakat payment from income reduction will be

Volume III, No. 1, Juli 2009 
Zulkipli Lessy: Zakat (Alms-Giving) Management...

considered as a tax (Chapter 9g Acts No. 17 Year 2000) and is believed to trigger the government's enthusiasm for zakat. Eventually, LAZ will be restructured in the governmental companies and private companies to become the Unit for Collecting Zakat under BAZ.

Acts No. 38 Year 1999 Acts are believed to be incomplete and to impede the management of zakat as it is being considered to be shared between the government and the community. Therefore, there are efforts to amend the acts based on four main issues.

First, equality between the entitled and the givers is addressed in Chapter 21 Zakat Acts, where it is stated that zakat collectors with their status as entitled can be sanctioned for misdeeds with three months in prison and can be fined 300 million rupiah. Givers are free from sanctions and only need to report their possessions (Chapter 14 Sections 1 and 2). The givers are obliged by shari'a and should be concerned with poverty, so there may be a need for legal sanctions for delinquent givers.

Second, Acts No. 38 Year 1999 and No. 17 Year 2000 seem to be contradictory in the relationship between tax and zakat. Chapter 14 Section 3 says that zakat that has been paid to the agents is taken from income subject to tax and that this is compatible with current acts. So zakat should reduce the taxable income of givers. Chapter 9g Acts No. 17 Year 2000 determines zakat reduction on income that should be taxed. The relationship between these two Acts raises the issue of whether the Zakat Acts amendment is consistent with the Tax Acts, whether the Tax Acts were amended to be consistent with the Zakat Acts, or whether both should be amended and designed so that they are compatible with each other.

Zakat in Indonesia should reduce all tax burdens in the manner in which this practice is implemented in Malaysia or in the way in which the Saudi Arabian government reduces tax obligation for zakat payers. In Indonesia, there is no such reduction.

Third, zakat management is implemented by the Central of Zakat. The Central of Zakat is represented by BAZNAS, which belongs to the government. A basic argument for creating BAZNAS was taken from interpreting the Qur'an, Chapter at-Taubah verse 60 , to say that the government has the authority to force people to give zakat. However, amid lack of public trust in the government, society may be cynical about the government's initiatives. Ironically, private institutions such as LAZ, Dompet Dhuafa, Pos Keadilan Peduli Umat, and RZI, are structured with modern zakat management not only to fulfill the immediate needs of society, but also to launch long-term programs to empower the poor.

Fourth, private institutions also began to audit their accountability on the zakat that they receive and manage. Audits should be conducted to engender public trust. If these community institutions do so, then what will be the government's response? Will the government merge private institutions of zakat into BAZ in the government? What should be the respective roles of government and community institutions in managing zakat? The government should be aware of these concerns in order to avoid the clash of interests before amending the Acts. The zakat Acts are still in debate even though they have not been revised. 
Zulkipli Lessy: Zakat (Alms-Giving) Management...

These are essential issues that should be resolved wisely. Instead of amending the Zakat Acts, vested interests should consult with those in the government, on one hand, and with individuals who want to take advantage of the conflict, on the other hand. Aggregate interests often occur in politics and law at elite levels to compromise resources. Democratization is developing in Indonesia, and all elements in society involved in this process are at risk via trial and error. The Zakat Acts aim for the high ground, but they are not yet fully implemented in society. In such a situation, the welfare of the poor and the destitute should be guaranteed when amending the Zakat Acts.

\section{Innovative Programs of Rumah Zakat Indonesia (RZI)}

Private zakat collecting institutions have more influence to strengthen and empower the poor than governmenal institutions, which tend to give only direct aid such as food and money. The direct aid tends not to educate but to ensure a dependence of the community upon the government. The private organizations have effective long term programs which not only strenthen societal educational programs but also economic programs. One of the private organizations which has such programs is Rumah Zakat Indonesia (RZI). RZI has four main programs, according to its website, www.rumahzakat.org, my observation, and interviews with the staff.

\section{A. Education}

Education is supported through scholarship programs for elementary and secondary school students who come from poor families. RZI guarantees their tuition minimums for one year, and it evaluates the students' performances to determine whether the scholarships are sustained or are terminated. Individual donors and institutions give money to RZI regularly. RZI deals not only with the students, but also with their parents to make sure that the parents are involved in this program.

\section{B. Health Care}

Health care is supported via service delivery programs, including free ambulances, free transportation, and free delivery clinics. The ambulances are operated to help poor families who are in emergency situations. When poor family members die, the ambulances bring the bodies to and from hospitals and then to the graves. When the poor cannot afford hospital fees, then some hospitals work together with RZI to help. The hospitals help with 500,000 rupiah (\$50), but most of the fees are paid by RZI.

The RZI clinic transportation program also provides free medical checkups in accessible locations such as schools, markets, and low income neighborhoods. The services include general checkups, family planning consultations, nutrition counseling, dental care, mother-baby care, circumcision for young boys, and tumor and cataract operations. RZI provides free clinics for pregnant mothers who come from low-income families. Other kinds of services are immunization and general consultation for mothers and their children. 
Zulkipli Lessy: Zakat (Alms-Giving) Management...

\section{Youth Care}

Youth care is supported via humanitarian aid delivered to victims in disaster and communal conflict areas. RZI's responsibility is dispatching health services including medicine, food, clothes, and tents. Besides these programs, RZI also focuses on spiritual aspects, economic empowerment, and education, which includes providing scholarships for children from victim families.

\section{Eco-Care}

Eco-care is supported as a non-interest micro-credit for poor households. By means of these loans, poor families can look for additional income. In a small business they run, perhaps they will change their status from zakat recipients to zakat givers. This program was established in 2005 in response to 11 million young people, or $36.7 \%$ of those between the ages of 15 and 24 , who were laid-off in Asian countries ("Badan," 2005). Getting a loan with interest is a serious problem among the poor families if they cannot pay the regular charges. Such persons typically receive only small loans and nonetheless must pay extremely high interest. Consequently, many of them cannot repay their loans. The RZI responds to their needs by giving them no-interest loans in order to revitalize the economy.

In order to earn the trust of society, RZI evaluates its programs and has them audited externally. For this latter purpose, the audits are done by external auditors. Usually, collection, management, and distribution details are revealed to the public. In 2006, the number of donors to the RZI was 26,000 individuals and institutions.

Based on an examination of published lists, the majority of RZI's recipients are Muslims. This suggests that zakat is due not only to Muslims but to nonMuslims as well, including Christians, Jews, Hindus, Buddhists, Confucians, and even those with no religious creed, such as the indigenous people who live on reserved areas in Indonesia. In the future, RZI should be concerned with the nonMuslim groups in order to create community welfare regardless of religion, gender, age, and ethnicity because RZI not only manages assets from zakat, but also from hibah, shadaqah, and infaq. Islam never restricts this welfare from being given to non-Muslims.

The Qur'an states there are eight groups of people entitled to zakat. However, I assert that RZI should learn from Dompet Duafa (DD), the other private zakat institution in Indonesia, because DD is inclusive in its reinterpreting the Qur'anic texts to be relevant to present-day situations. The Qur'an stresses that slavery is the enemy of humanity, but even though slavery was abolished during the history of Islam, slavery still emerges in other forms such as sex slavery. The discourse in the Qur'an about freeing slaves should be extended in similar context to current situations. Slavery, according to DD, includes female sex workers because they are in bondage to the owners of the brothels. Some of them may work under forcible control.These workers need aid and advocacy via zakat and the zakat instituions to provide programs to help them.

Zakat assets can be used to help the sex workers achieve release from the bondage of brothels and a return to their normal lives. DD made an important leap 
Zulkipli Lessy: Zakat (Alms-Giving) Management...

in its interpretation of the eight groups of recipients who are entitled to zakat. Some traditional Muslilm scholarsrigidly interpret this verse and will not allow zakat to be donated except to the traditional versions of the eight groups. Some people in society believe that prostitution is sinful, but others say that the women had no other choices due to discrimination and marginalization and even injustice. Advocacy for prostitutes to receive zakat in order to leave prostitution is important. With zakat money, they may be able to open or join socially respectable businesses and start new lives free from their previous virtual bondage.

\section{Conclusions}

To optimize the work of both government and private zakat institutions, it is considered advisable and beneficial for both sides to collaborate in mutual respect and fair competitiveness.It isa fact that private zakat institutions have worked well in serving the poor. The government, with its authority, should not eliminate the roles of the private institutions. Apart from the existing polemics, these two institutions should collaborate to eradicate poverty instead of competing for zakat funds.

Both government and priovate zakat institutions should involve external auditors in assessing their funds. The results of audits should be published to educate society and to encourage people toward giving zakat. People will thereby know how the funds are collected and distributed to poor people, orphans, and other worthy recipients.

In managing zakat funds, there are already some aspects which can be proudly built upon, as evidenced by RZI management. This institution not only fills moment-to-moment needs in many of its programs, such as providing food for poor people, but it also has sustainable programs to empower economic advances for the poor, such as loans of capital without interest and business training. There are also programs to help educate the poor by means of scholarships and the funding of new buildings for schools.

The government should learn from the private zakat collecting foundations (LAZ) which have sustainable programs to empower the poor through education and economic programs. The private zakat collecting institutions cannot be considered as competitors with the government for zakat funds but they should be considered as partners in poverty eradication.

\section{REFERENCES}

Ali, M.D. (1998). Sistem ekonomi Islam zakat dan wakaf. (The system of Islamic economy of zakat and waqf). Jakarta: University of Indonesia Press.

Arjomand, S.A. (1998). Philanthropy, the law, and public policy in the Islamic world before the modern era. In W.F. Ilchman, S.N. Katz, \& E.L. Queen II. (Eds.). Philanthropy in theworld's traditions (pp. 165-178). Bloomington: IU Press.

"Badan." (2005). Badan pusat statistik. (Statistics Central Bureau). Retrieved from http://www.bps.go.id.

Volume III, No. 1, Juli 2009 
Zulkipli Lessy: Zakat (Alms-Giving) Management...

Bamualim, C.S., \& Abubakar, I. (2005). Revitalisasi filanthropi Islam: Studi kasus lembaga zakat dan wakaf di Indonesia. (Revitalization of Islamic philanthropy: A case study of zakat and waqf institutions in Indonesia). Jakarta: Pusat Bahasa \& Budaya Universitas Islam Negeri Syarief Hidayatullah.

Benthall, J. (1999). Financial worship: The Quranic injunction to alms-giving. The Journal of theRoyal Antbropological Institute, 5(1): 27-42.

Djatnika, R. (1982). Tanah wakaf. Surabaya: Al-Ikhlas.

Djuanda, G., Sugiarto, A., Lubis, I., Trisilo, R.B., Ma'mun, T.B.M, \& Chalid, A. (2006). Pelaporan zakat pengurang pajak, penghasilan (Zakat reports and income tax reduction). Jakarta: Rajawali Press.

Doa, M.D. (2005). Menggagas pengelolaan zakat oleh negara (Zakat under state management). Jakarta: Nuansa Madani.

"Dompet." (2009). Mengungkap sistem penilaian ISR award 2009. (Exploring the system of assessment through the ISR award 2009. Retrieved from http://www.dpudt-jogja.org.

Hassan, M.A. (2006). Zakat dan infaq: Salah satu solusi mengatasi problema sosial di Indonesia. (Zakat and infaq: One of the solutions for social problems in Indonesia). Jakarta: Putra Grafika.

Juwaini, A. (2009). "Zakat management in Indonesia and zakat global synergy." Retrieved from http://amilzakat.blogspot.com.

Kahf, M. (1999, April). The performance of the institution of zakat in theory and practice. A Paper Presented in the Internasional Conference on Islamic Economics toward the $21^{\text {st }}$ Century: Kuala Lumpur Malaysia.

Khalidi, T. (2008). The Qur'an: A new translation. New York: Penguin Classics.

"Komisi." (2009) KPK. Retrieved from www.kpk.go.id.

Kozlowski, G.C. (1998). Religious authority, reform, and philanthropy in the contemporary Muslim world. In W.F. Ilchman, S.N. Katz, \& E.L. Queen II (Eds.). Philanthropy in theworld's traditions (pp. 279-308). Bloomington: Indiana University Press.

Mas'udi, M.F. (1995). Zakat: Konsep harta yang bersih. (Zakat: the concept of purified wealth).In Budhy Munawar-Rachman (Ed.). Kontekstualisasi doktrin Islam dalam sejarah. (Contextualization of Islamic doctrines in history)(pp. 3037). Jakarta: Paramadina.

McChesney, R.D. (1991). Waqf in Central Asia: Four hundred years in the bistory of a Muslim shrine, 1480-1889. Princeton, NJ: Princeton University Press.

Noval, A.E. (1982). Essentials of Islam series "al-zakat" the poor due. Cairo: The Supreme Council for Islamic Affairs.

"Pengelolaan." (2008) Pengelolaan zakat. (Zakat management). Kompas. Retrieved from http:/ /www.kompas.com.

"Profil." (2007). Rumah zakat Indonesia. Retrieved from (http://www.rumahzakat.org.

Public Interest Research and Advocacy Center (PIRAC). (2005). Investing in ourselves: Givingand fund raising in Indonesia. Manila: Asian Development Bank. 
Zulkipli Lessy: Zakat (Alms-Giving) Management...

Qardhawi, Y. (2005). Spektrum qakat dalam membangun ekonomi kerakyatan. (The spectrum of zakat in building social economy). Jakarta: Media Intelektual.

Qardhawi, Y. (2007). Hukum zakat: Study komparatif mengenai status dan filsafat qakat berdasarkan Qur'an dan Hadits (Zakat law: A comparative study on the status and zakat philosophy according to the Qur'an and Hadits). Jakarta: Litera AntarNusa.

Sabiq, S. (1992). Fiqih sunnah. (Islamic Jurisprudence). Jakarta: Daar al-Fikr.

Saepullah, A. (2001). Amil zakat di persimpangan jalan. (Zakat collector at a crossroads). Republika. Retrieved from http://www.republika.co.id.

Salim, A. (2008). The shift in zakat practice in Indonesia: From piety to an Islamic sociopolitical-economic system. Chiang Mai: Silkwormbooks.

Senturk, O.F. (2007). Islam in practice: A comprehensive guide to zakat charity in Islam. Somerset, NJ: The Light.

Shaik, A.A. (1980). Zakat---survey of Qur'anic texts and their definitions in shari'ah and contemporary economics. In M. R. Zaman (Ed.). Some aspects of the economics of zakat (pp. 3-67). Indiana: American Trust Publications.

Suyitno, Junaidi, H., \& Abdushomad, M.A. (2005). Anatomi fiqh zakat: Potret dan pemahaman badan amil zakat Sumatra Selatan. (Anatomy of zakat: A portrait and understanding of the zakat collecting board in South Sumatra). Yogyakarta: Pustaka Pelajar. 